\title{
Fungal endophyte effects on intake, health and liveweight gain of grazing cattle
}

\author{
G.P. COSGROVE, C.B. ANDERSON and T.R.N. BERQUIST \\ AgResearch Grasslands, Private Bag 11008, Palmerston North
}

\begin{abstract}
The direct effects of fungal endophyte-produced alkaloids on dairy beef cattle were determined in early summer 1992 and in autumn of 1993 and 1994. Endophyte level (nil vs high) or strain (wildtype vs selected 187BB) did not affect liveweight gain (LWG), but in 1994 weaners on nil endophyte consumed more dry matter than those on either endophyte treatment. The presence of clover enhanced LWG, reflected in higher dry matter intake in autumn 1993. Under the severe endophyte challenge of 1994, clover reduced the severity of ryegrass staggers even though the daily intake of lolitrem B was higher in the presence of clover. Under the rotational grazing management contrast imposed in 1994, followers had lower LWG than leaders and tended to have higher daily intake of lolitrem B. Grazing management effects on ergovaline intake were inconsistent and differed between endophyte strain and clover level. Animal responses to endophyte strain under contrasting conditions during each measurement period were related to daily alkaloid intake when scaled to liveweight. It is concluded that under the environmental conditions experienced in the Manawatu, endophyte alkaloids have minimal direct effect on cattle performance, although the reduction in ryegrass staggers by clover presence and its elimination by using a selected endophyte have important practical effects. Indirect effects through pasture production, composition or persistence may be more important to animal performance.
\end{abstract}

Keywords: alkaloid intake, cattle, endophyte, ergovaline, herbage intake, liveweight gain, lolitrem $\mathrm{B}$, peramine

\section{Introduction}

Ryegrass endophyte (Acremonium lolii, Latch, Christensen \& Samuels) causes staggers and other disorders in cattle but effects have not been studied in detail, in contrast to sheep. A related endophyte (Acremonium coenophialum, Morgan-Jones \& Cams) in tall fescue (Festuca arundinacea Schreb.) reduces intake and liveweight gain (LWG) in grazing cattle (Chestnut et al. 1991; Fribourg et a/. 1989) and sheep (Debessai et al. 1993; Hannah et al. 1990).

Endophyte effects on grazing cattle may be direct, through ingestion of toxins, or indirect, through effects on the growth or composition of pasture. Direct effects result from both the concentration of alkaloids in the herbage ingested and from the total alkaloid intake. Direct effects reported in sheep have included elevated body temperature (Fletcher 1993), tyegrass staggers, and reduced LWG. Recent results indicate inconsistent associations of visible effects in cattle with concentrations of alkaloids, mainly ergovaline, in the herbage on offer (H.S. Easton, pers. comm.). Trials with young dairy cattle (McCallum \& Thomson 1994) or lactating cows (Thorn et al. 1994) have shown no effects of endophyte on animal performance; however, alkaloid intakes were not reported.

This paper reports results of measurements made over 1992/93 and 1993/94 within a larger trial, to examine the relationship between endophyte effects on animals and the dietary concentration and intake of causal toxins. Some preliminary results of the larger trial, evaluating the effects of wild-type and a selected endophyte strain (187BB) on pasture and animal performance, have been reported (Clark 1992; Cosgrove et al. 1993).

\section{Materials and methods}

\section{Site and treatments}

The experiment was located at the AgResearch Aorangi Lowland Research Station, Palmerston North. The main experiment was a $3 \times 2$ factorial laid out in a randomised complete block design with 3 replications. Ryegrass (Lolium perenne cv. Grasslands Nui) with 3 endophyte level and strain combinations (endophyte strain 187BB [98.3\% tillers infected]; wild-type endophyte [95\% tillers infected]; and nil endophyte $[2.7 \%$ tillers infected]), were each sown with or without white clover (Trifolium repens cv. Grasslands Kopu) into a cultivated seedbed in March 199 1. Paddocks not sown with clover received $250 \mathrm{~kg} \mathrm{~N} / \mathrm{ha} / \mathrm{yr}$ as urea, in 5 applications of $50 \mathrm{~kg}$ each in August, September, October, December and March. All treatments received maintenance superphosphate at $250 \mathrm{~kg} / \mathrm{ha}$. 


\section{Management}

Paddocks of 0.5 ha were continuously stocked with yearling Friesian bulls at 6.0 /ha from August to December in both years and with weaner bulls from January to early May in 1993. For autumn 1994 additional grazing treatments were added. On one half of each of the plots of the wild-type endophyte treatments, weaners were continuously stocked at $\mathbf{8 . 0 /}$ ha to provide a core treatment for comparison with previous years. For the other half of these plots, and the nil endophyte and strain $187 \mathrm{BB}$ treatment plots, weaners from each replicate were pooled into leaders and followers and grazed rotationally around the field replicates using a IO-day grazing duration ( 5 days by leaders, 5 days by followers) and 20-day spell sequence to allow comparison of leaders (high allowance, leafy pasture) vs followers (low allowance, less leaf and more stem), as a management to modify the exposure to endophyte-related toxins. Additional (put and take) grazing animals were used to keep endophyte and clover treatments at a common mean sward height, as measured with a rising-plate meter. This height varied slightly with season.

\section{Measurements}

Liveweight and liveweight gain: Animals were weighed monthly following a 5-hour fast and LWG calculated. To relate LW and LWG to intake measurements, LW at the end of the month and LWG for the month during which the intake measurement was conducted, were used in all calculations.

Animal health: Incidence of ryegrass staggers, scored on a $0-5$ scale $(0=$ no visible symptoms; 5 = unable to be moved from paddock, Keogh 1973), was assessed weekly during February to April of each year. Body temperatures were determined on 10, 16 and 25 March 1993, and 23 February and 23 March 1994 using a digital rectal thermometer.

Daily herbage intake: Intake was estimated for periods in December 1992 (summer) and in March of 1993 and 1994 (autumn) using intra-ruminal controlled-release capsules (Captech New Zealand Ltd) containing a matrix of chromium sesquioxide $\left(\mathrm{Cr}_{2} \mathrm{O}_{3}\right)$. Faecal grab samples were freeze dried, bulked across days on an equal dry weight basis and ground. Chromium concentration was assessed according to Lee et al. (1986) and adjusted for background chromium (of soil and herbage origin). Capsule release rate (RR) was determined from the drop-off in chromium concentration in end-point faecal samples taken from a subgroup of animals. Individual faecal output (FO) was calculated as $\mathrm{FO}=\mathrm{RR} /[\mathrm{Cr}]$. Group mean herbage intake (I) using an in vitro digestibility (D) estimate for each plot, was calculated as $\mathrm{I}=\mathrm{FO} / \mathrm{l}-\mathrm{D}$

Diet quality and alkaloid concentrations: Hand-plucked samples of herbage were selected by two operators following visual observations of animal grazing behaviour to provide representative diet samples. Each operator plucked from at least 5 sites covering the plot and this herbage was bulked into one sample for the plot. This procedure was repeated on 2 days in week 1 , and 2 days in week 2 for December 1992 and March 1993. In March 1994, samples were collected on 3 individual days over a period of 2 weeks. Samples from individual days were bulked, freeze dried, ground, and analysed for in vitro digestibility and concentrations of lolitrem B, ergovaline and peramine.

\section{Statistical analysis}

For December 1992 and March 1993, main effects and interactions were compared by ANOVA using rep interactions as error. For the modified management in March 1994 with replicate groups pooled, effects were tested against animal interactions.

The period from September 1992 to April 1993 was cooler than average, with a particularly wet December (Table 1). In contrast, 1994 was drier than average during January-March and slightly warmer than average during February.

Table 1 Weather conditions at the trial site during spring, summer and autumn of 1992/93 and 1993/94.

\begin{tabular}{|c|c|c|c|c|c|c|}
\hline \multirow[t]{2}{*}{ Month } & \multicolumn{2}{|c|}{ Rainfall } & \multirow{2}{*}{$\begin{array}{l}\text { 20-year } \\
\text { Mean }\end{array}$} & \multicolumn{2}{|c|}{$\begin{array}{l}\text { Mean daily maximum } \\
\text { air temperature }\end{array}$} & \multirow{2}{*}{$\begin{array}{l}\text { 20-year } \\
\text { Mean }\end{array}$} \\
\hline & $1992 / 93$ & $1993 / 94$ & & $1992 / 93$ & $1993 / 94$ & \\
\hline & \multicolumn{3}{|c|}{ 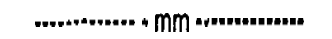 } & \multicolumn{3}{|c|}{$\ldots \ldots{ }^{\circ} \mathrm{C}+\cdots \cdot \cdots+$} \\
\hline September & 85.8 & 75.2 & 78.9 & 12.7 & 12.7 & 15.1 \\
\hline October & 81.8 & 59.4 & 75.7 & 15.3 & 16.4 & 16.7 \\
\hline November & 52.2 & 124.4 & 59.5 & 18.0 & 16.6 & 18.7 \\
\hline December & 197.2 & 81.8 & 69.3 & 19.2 & 18.8 & 20.8 \\
\hline January & 55.6 & 30.8 & 59.6 & 19.3 & 22.2 & 22.6 \\
\hline February & 40.4 & 13.0 & 50.6 & 20.2 & 23.8 & 22.9 \\
\hline March & 68.6 & 50.6 & 70.2 & 19.1 & 20.2 & 21.6 \\
\hline April & 58.8 & 45.2 & 59.9 & 16.6 & 18.8 & 18.8 \\
\hline
\end{tabular}

\section{Results}

Herbage intake and animal performance

Summer: Herbage DM intake and LW were similar for each endophyte and clover treatment. The overall mean intake of $8.4 \mathrm{~kg} \mathrm{DM} / \mathrm{head} /$ day for yearling bulls which averaged $409 \mathrm{~kg} \mathrm{LW}$ represented a mean intake of $2.1 \%$ of $\mathrm{LW}(0.021 \mathrm{~kg} \mathrm{DM} / \mathrm{kg} \mathrm{LW} /$ day $)$. Endophyte 
status did not affect LWG for the month during which intake was estimated but LWG was significantly higher for clover $(1.21 \mathrm{~kg} / \mathrm{hd} /$ day $)$ than for nil clover $(0.91$ $\mathrm{kg} / \mathrm{hd} /$ day) treatments.

Autumn 1993: As for yearling bulls in spring, endophyte did not affect DM intake of weaners $(3.71 \mathrm{~kg} / \mathrm{hd} /$ day), which was $1.8 \%$ of LW. However, DM intake (4.0 vs $3.4 \mathrm{~kg} / \mathrm{hd} /$ day), LW (216 vs $190 \mathrm{~kg}$ ) and LWG (0.57 vs $0.37 \mathrm{~kg} / \mathrm{hd} / \mathrm{day})$ were each significantly $(\mathrm{P}<0.05, \mathrm{P}<0.01$ and $\mathrm{P}<0.01$, respectively) higher for clover than for nil clover treatments. Ryegrass staggers occurred only on wild-type endophyte plots. Incidence $(50 \%)$ and mean severity $(1.2 ; 0-5$ scale) were low and did not differ between clover levels.

Autumn 1994: Under the rotational grazing management applied to all treatment combinations, endophyte status affected DM intake, weaners on nil endophyte (4.6 $\mathrm{kg} \mathrm{DM} / \mathrm{hd} / \mathrm{day})$ eating significantly more than those on either wild-type or 187BB endophytes (mean $3.7 \mathrm{~kg}$ $\mathrm{DM} / \mathrm{hd} /$ day) (Table 3). This difference was reduced, but still significant when scaled to $\mathrm{LW}$ because weaners on nil endophyte $(191 \mathrm{~kg} ; 0.024 \mathrm{~kg} \mathrm{DM} / \mathrm{kg} \mathrm{LW} / \mathrm{day})$ were heavier than those on wild-type $(171.5 \mathrm{~kg} ; 0.021$ $\mathrm{kg} \mathrm{DM} / \mathrm{kg} \mathrm{LW/day)}$ or 187BB (182.5 kg; $0.021 \mathrm{~kg} \mathrm{DM} /$ $\mathrm{kg} \mathrm{LW/day).} \mathrm{However,} \mathrm{LWG} \mathrm{was} \mathrm{similar} \mathrm{for} \mathrm{all}$ endophyte treatments, but higher for clover $(0.51 \mathrm{~kg} / \mathrm{day})$ compared with nil clover treatments $(0.13 \mathrm{~kg} / \mathrm{hd} / \mathrm{day})$ and higher for leaders $(0.76 \mathrm{~kg} / \mathrm{hd} /$ day $)$ than followers $(0.24 \mathrm{~kg} / \mathrm{hd} / \mathrm{day})$ on clover plots, but leaders and followers on nil clover treatments $(0.13 \mathrm{~kg} / \mathrm{hd} /$ day $)$ did not differ (clover $x$ management interaction, $P<0.01$ ). Ryegrass staggers peak incidence $(100 \%)$ and peak severity (2.8) were higher in 1994 than in 1993. The peak severity was higher on nil clover (3.7) compared with clover (1.85) treatments, but grazing management had no effect.

\section{Alkaloid concentrations and intakes}

Low levels of lolitrem B detected in the nil endophyte and $187 \mathrm{BB}$ treatments reflect the low-level contamination by endophyte-infected plants in these plots. For completeness zeros are recorded in Table 3, and in these instances statistical significance refers to the comparison between wild-type and 187BB.

Summer: Diets obtained from 187BB treatments contained effectively zero lolitrem B, but were higher in ergovaline concentration $(0.48 \mathrm{mg} / \mathrm{kg})$ than wildtype $(0.30 \mathrm{mg} / \mathrm{kg})$ (Table 2$)$. As a result, bulls grazing 187BB consumed more ergovaline $(5.4 \mathrm{mg} /$ day) than those grazing wild-type plots $(2.9 \mathrm{mg} /$ day $)$. Peramine concentration, and therefore daily peramine intake, were
Table 2 Effect of endophyte strain on diet alkaloid concentrations and daily intake of alkaloids in summer 1992 (December) and autumn 1993 (March).

\begin{tabular}{|c|c|c|c|}
\hline & $\begin{array}{r}\text { Endophy } \\
\text { Wild-type }\end{array}$ & $\begin{array}{l}\text { strain } \\
87 \mathrm{BB} \text { si }\end{array}$ & $\begin{array}{c}\text { Statistical } \\
\text { gnificance }\end{array}$ \\
\hline \multicolumn{4}{|l|}{ Summer 1992} \\
\hline Lolitrem B (mg/kg) & 0.48 & 0.01 & $* \star 1$ \\
\hline Ergovaline $(\mathrm{mg} / \mathrm{kg})$ & 0.30 & 0.48 & NS \\
\hline Peramine (mg/kg) & 10.51 & 9.17 & * \\
\hline Lolitrem B intake (mg/day) & 4.45 & 0.85 & $\star *$ \\
\hline Ergovaline intake (mg/day) & 2.92 & 5.44 & * \\
\hline Peramine intake (mg/day) & 99.50 & 107.70 & $* *$ \\
\hline \multicolumn{4}{|l|}{ Autumn 1993} \\
\hline Lolitrem B (mg/kg) & 1.33 & 0.17 & *ht \\
\hline Ergovaline $(\mathrm{mg} / \mathrm{kg})$ & 0.40 & 0.80 & \#th \\
\hline Peramine (mg $/ \mathrm{kg}$ ) & 33.40 & 32.49 & $* *$ \\
\hline Lolitrem B intake (mg/day) & 5.27 & 0.63 & \#+ \\
\hline Ergovaline intake (mg/day) & 1.58 & 3.15 & $+h$ \\
\hline Peramine intake (mg/day) & 132.70 & 129.60 & $*$ *t* \\
\hline
\end{tabular}

similar for both endophyte treatments. The presence or absence of clover did not significantly affect diet alkaloid concentration.

Autumn 1993: Alkaloid concentrations were higher in autumn 1993 than in summer 1992 (Table 2). Trends among endophyte treatments, however, were similar to summer, 187BB having only small concentrations of lolitrem B, but higher ergovaline $(0.8 \mathrm{mg} / \mathrm{kg})$ than wildtype $(0.4 \mathrm{mg} / \mathrm{kg})$ and similar concentration of peramine $(32.95 \mathrm{mg} / \mathrm{kg})$. Daily intake of ergovaline was higher on $187 \mathrm{BB}(3.15 \mathrm{mg} /$ day $)$ than on wild-type (1.59 mg/day).

Autumn 2994: Diets obtained from 187BB treatments were higher in ergovaline, lower in lolitrem $\mathrm{B}$, and similar in peramine concentration compared with wildtype, under rotational grazing (Table 3). Daily toxin intake reflected these trends in concentrations. Although clover or management did not significantly affect DM intake or alkaloid concentrations, clover $\times$ management and endophyte $x$ clover interactions were detected in ergovaline intake. Leaders had a similar daily intake of ergovaline at both levels of clover ( $3.7 \mathrm{mg} /$ day), but followers consumed more ergovaline in the absence of clover $(5.7 \mathrm{mg} /$ day $)$ than in the presence $(2.6 \mathrm{mg} /$ day $)$. The endophyte $x$ clover interaction resulted from the higher daily intake of ergovaline in the absence of clover (10.8 mglday) compared with the presence (6.9 $\mathrm{mg} /$ day) on 187BB. Peramine intake was significantly higher for leaders (38.5 mglday) than for followers (30.9 mg/day). 
Table 3 Effect of endophyte level and strain, clover and grazing management on several indicators of animal performance, diet quality, diet alkaloid concentrations and daily intake of alkaloids in autumn 1994 (March), for rotationally grazed cattle.

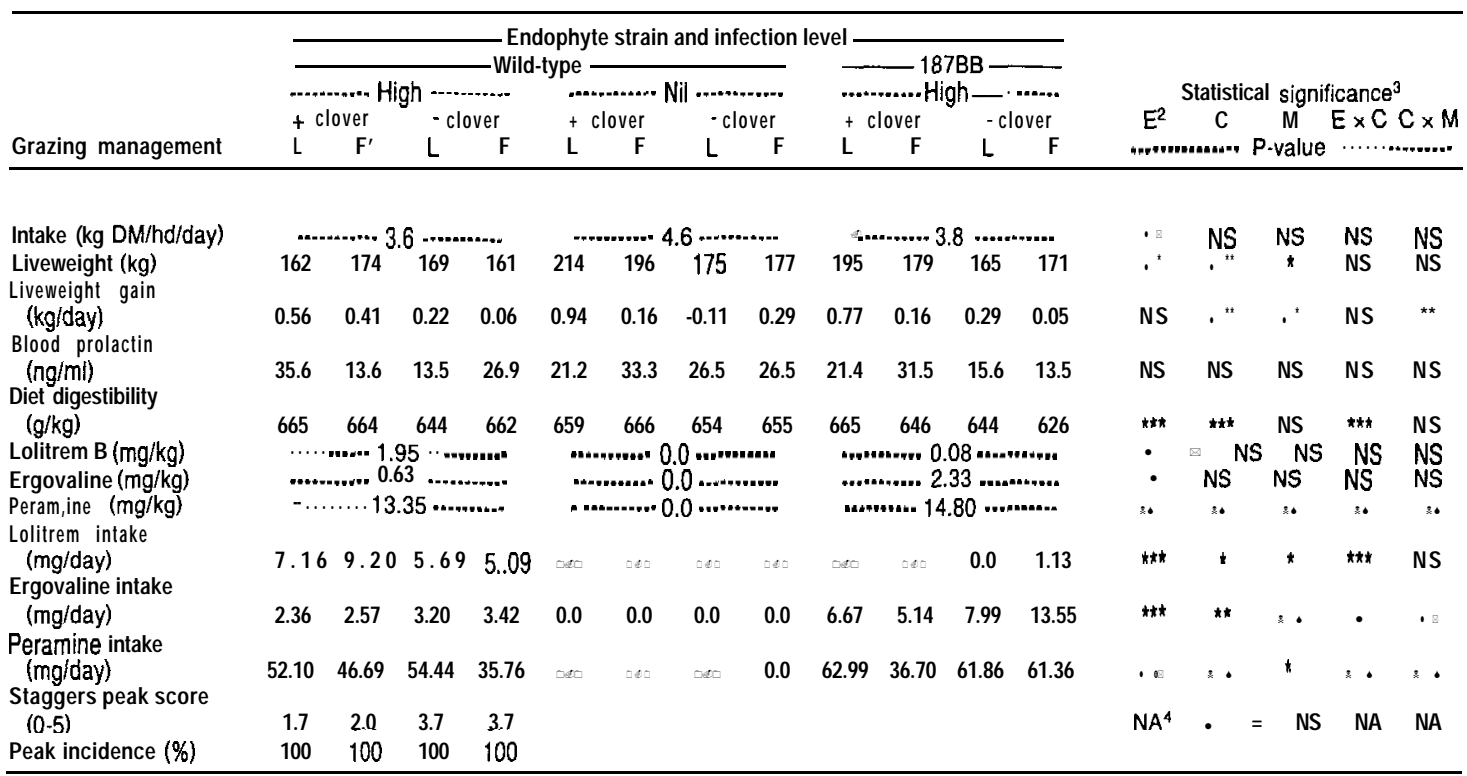

$L, F=$ Leaders and followers in rotational grazing

$2 \mathrm{E}, \mathrm{C}, \mathrm{M}=$ Endophyte. Clover and Management (leaders vs followers) main effects and interactions

$3 * * * * *$ and NS $=$ Statistical significance at $P<0.001, P<0.01$ and $P<0.05$ and not significant, respectively

$4 \mathrm{NA}=$ Effect not applicable

\section{Animal health}

Endophyte and clover treatments had no effect on weaner rectal temperatures in 1993. In 1994, on a cool day (daily max: $17.8^{\circ} \mathrm{C}$ ), weaners grazing $1877 \mathrm{BB}$ had slightly elevated $(\mathrm{P}<0.01)$ temperature $\left(39^{\circ} \mathrm{C}\right)$ compared with wild-type or nil endophyte treatments $\left(38.7^{\circ} \mathrm{C}\right)$. On a warmer day $\left(23^{\circ} \mathrm{C}\right)$, earlier in the season prior to the peak incidence of staggers, followers on nil clover $\left(39.1^{\circ} \mathrm{C}\right)$ had a higher temperature than leaders $(38.1$ "C), but leaders and followers on clover did not differ (clover $x$ management interaction, $\mathrm{P}<0.001)$.

\section{Discussion}

In general, endophyte infection level and strain had minimal effects on economic performance of dairy beef animals, consistent with results obtained with dairy cattle in other North Island regions (McCallum \& Thomson 1994; Thorn et al. 1994), but different from results reported for sheep in Canterbury (Fletcher et al. 1990). Our results describe LWG and health in relation to both daily DM intake and toxic alkaloid diet concentrations and intake. Estimates of DM intake for each of the three measurement periods are consistent with those predicted from standard feeding tables (NRC 1984), indicating that the technique provided reliable estimates. Although absolute intake differed between yearlings and weaners, when adjusted for LW to allow comparison across seasons, DM intakes ranged from 1.8 to $2.2 \%$ of $\mathrm{LW}$. This level of intake is below what could have been expected with ad libitum intake. This reflects the relatively short pasture height maintained to ensure animal exposure to endophyte-related alkaloids, particularly those concentrated towards the base of tillers (e.g., lolitrem B). The high intake of weaners on the nil endophyte treatment in 1994 was not reflected in higher LWG and cannot be explained.

Measurements in summer 1992 provide a benchmark for animal intake and diet composition in the absence of clinical effects of endophyte. In contrast, measurements in March were timed to coincide with the peak incidence of staggers. Diet concentrations of lolitrem $\mathrm{B}$, ergovaline and peramine were higher in autumn than summer. However, calculation of alkaloid intake per unit of LW shows that ergovaline intakes were approximately similar in summer and autumn, for each endophyte $(0.0075 \mathrm{mg} / \mathrm{kg} \mathrm{LW} /$ day and $0.0144 \mathrm{mg} /$ $\mathrm{kg} \mathrm{LW} /$ day for wild-type and $187 \mathrm{BB}$, respectively) because of the slightly higher DM intake in summer $(0.021 \mathrm{~kg} / \mathrm{kg} \mathrm{LW} /$ day $)$ than autumn $(0.018 \mathrm{~kg} / \mathrm{kg}$ $\mathrm{LW} /$ day). This is consistent with the lack of any ergovaline-related symptoms in either summer or 
autumn. For lolitrem B, which caused a low severity of staggers in autumn 1993 but none in summer, intake per unit LW more than doubled from summer $(0.011 \mathrm{mg}$ lolitrem B $/ \mathrm{kg} \mathrm{LW} /$ day) to autumn $(0.026 \mathrm{mg} / \mathrm{kg} \mathrm{LW} /$ day) and was even higher in autumn $1994(0.041 \mathrm{mg} / \mathrm{kg}$ LW/day). Based on similar calculations, a comparison of autumn 1993 with autumn 1994 shows a large increase in ergovaline intake on both wild-type (0.008-0.017 $\mathrm{mg} / \mathrm{kg} \mathrm{LW} /$ day $)$ and 187BB (0.0 $16-0.048 \mathrm{mg} / \mathrm{kg} / \mathrm{day})$, consistent with the detection of elevated body temperatures in 1994. Thus, while the calculations of alkaloid intakes cannot be used as dose responses, they indicate that intakes of lolitrem B at or above $0.026 \mathrm{mg} /$ $\mathrm{kg} \mathrm{LW/day} \mathrm{are} \mathrm{required} \mathrm{for} \mathrm{moderate} \mathrm{staggers} \mathrm{severity,}$ and similarly, intakes of ergovaline at $0.048 \mathrm{mg} / \mathrm{kg} \mathrm{LW} /$ day for ergovaline-related effects in cattle, at least under the environmental temperatures experienced in Manawatu. In contrast, Debessai et al. (1993) reported reduced feed intake and reduced LWG in lambs at daily ergovaline intakes as low as $0.026 \mathrm{mg} / \mathrm{kg} \mathrm{LW} /$ day.

Within a measurement period, alkaloid intakes reflect concentrations in the diet sample because of the similarity among treatments in DM intake. However, between periods, prediction of animal responses (i.e., staggers) is most reliable when alkaloid intakes are related to LW. Predictions based on pasture assessment only (pasture on offer or a diet sample) are unlikely to be reliable when treatment affects intake.

While endophyte affected body temperature, heat stress was not observed. The elevated temperature can be related to the higher ergovaline intake on 187BB compared with wild-type endophyte, and for weaners grazed as followers on nil clover plots. Thus the potential for heat stress exists, but for visible symptoms, higher ambient temperatures may be required.

The grazing management contrast between leaders and followers resulted in predictable effects on LWG. However, effects on the diet were less clear. The dry conditions during summer 1994 severely reduced pasture growth rate. The contrast in pasture mass and composition offered to leaders and followers diminished with each successive rotation, compared with the contrast when the experiment began in January, such that each group was grazing drought-affected pasture with a high proportion of dead material.

\section{Conclusions}

Direct effects of endophyte alkaloids on cattle intake and liveweight gain were small and influenced by season. Where effects on cattle are likely, use of selected lolitrcm B-free endophyte, encouragement of high clover proportion in pastures and avoiding grazing to low residuals will reduce the severity of staggers.

\section{ACKNOWLEDGEMENTS}

Drs Brian Tapper and Geoff Lane for conducting laboratory alkaloid analyses. The New Zealand Meat Research and Development Council for financial support for the measurements reported here, and Dr Syd Easton for leadership of the MRDC project.

\section{REFERENCES}

Chestnut, A.B.; Fribourg, H.A.; McLaren, J.B.; Keltner, D.G.; Reddick, B.B.; Carlisle, R.J.; Smith, M.C. 1991. Effects of Acremonium coenophialum infestation, bermudagrass, and nitrogen or clover on steers grazing tall fescue pastures. Journal of production agriculture 4: 208-2 13.

Clark, D.A. 1992. Beating ryegrass staggers. Proceedings of the Ruakura Farmer's Conference, pp 87-92.

Cosgrove, G.P.; Anderson, C.B.; Mainland, R.A.; Saunders, C.J.; Hume, D.E. 1993. Fungal endophyte level and strain effects on pastures and cattle liveweight gain, pp 1 06-1 10. In.' D.E. Hume, G.C.M. Latch and H.S. Easton (eds.) Proceedings of the Second International Symposium on Acremonium Grass Interactions.

Debessai, W.; Luick, B.R.; Cheeke, P.R. 1993. Effects of feeding endophyte-infected tall fescue seed on lamb performance and serum prolactin, pp 11 1113. In: D.E. Hume, G.C.M. Latch and H.S. Easton (eds.) Proceedings of the Second International Symposium on Acremonium/Grass Interactions.

Fletcher, L.R. 1993. Heat stress in lambs grazing ryegrass with different endophytes, pp 114-1 18. In: D.E. Hume, G.C.M. Latch and H.S. Easton (eds.) Proceedings of the Second International Symposium on Acremonium/Grass Interactions: 114-I 18.

Fletcher, L.R.; Hoglund, J.H.; Sutherland, B.L. 1990. The impact of Acremonium endophytes in New Zealand, past, present and future. Proceedings of the NZ Grassland Association 52: 227-235.

Fribourg, H.A.; McLaren, J.B.; Chestnut, A.B.; Waller, J.C. 1989. Recent effects of Acremonium coenophialum on the performance of beef cattle grazing Festuca arundinacea. Proceedings of the XVI International Grassland Congress: 705-706.

Hannah, S.M.; Paterson, J.A.; Williams, J.E.; Kerley, M.S.; Miner, J.E. 1990. Effects of increasing dietary levels of endophyte-infected tall fescue seed on diet digestibility and rumen kinetics in sheep. Journal of animal science 68: 1693-1 701 .

Keogh, R.G. 1973. Induction and prevention of ryegrass staggers in grazing sheep. New Zealand journal of experimental agriculture I: 55-57. 
Lee, J.; Fisher, M.T.; Mare, B. 1986. Comparison of techniques for chromium sesquioxide analysis in marker studies. Journal of the science of food and agriculture 37: 366-372.

McCallum, D.A.; Thomson, N.A. 1994. The effect of different perennial ryegrass cultivars on dairy animal performance. Proceedings of the NZ Society of Animal Production 54: 87-90.
N.R.C. 1984. Nutrient Requirements of Beef Cattle. Sixth Revised Edition. National Academy. Bess, Washington, DC.

Thorn, E.R.; Clark, D.A.; Prestidge, R.A.; Clarkson, F.H.; Waugh, CD. 1994. Ryegrass endophyte, cow health and milk solids production for the 1993/94 season. Proceedings of the NZ Grassland Association 56: 259-264. 